\title{
Behavioural Responses of African Catfish (Clarias gariepinus) Exposed to Different Chemicals
}

\author{
Bridget, D. Ayoku ${ }^{1}$, Leo, C. Osuji ${ }^{1}$ and Mudiaga, C. Onojake ${ }^{1,2^{*}}$ \\ ${ }^{1}$ Department of Pure and Industrial Chemistry, University of Port Harcourt, \\ P.M.B 5323, Choba, Port Harcourt, Nigeria \\ ${ }^{2}$ Centre for Marine Pollution Monitoring and Seafood Safety, University of Port \\ Harcourt, P.M.B 5323, Choba, Port Harcourt, Nigeria \\ *Corresponding author.E-mail: ononed@yahoo.com, mudiaga.onojake@uniport.edu.ng \\ https://doi.org/10.12982/CMUJNS.2020.0013 \\ Received: July 19, 2018 \\ Revised: May 8, 2019 \\ Accepted: June 19, 2019
}

\begin{abstract}
The African Catfish (Clarias gariepinus) was exposed to different toxicant concentrations of 100, 200, 300, 400, $500 \mathrm{mg} / \mathrm{L}$ using a static nonrenewable bioassay method. Another set up without the toxicant was set up to serve as control. Two replicate concentrations for the different toxicants used in thirty (30 L) litres rectangular tanks were also set up. The aquariums were filled to fifteen-liter mark, loaded with ten fishes and properly labelled. Parameters such as cumulative average value of operculum movement; tail beat frequency, cumulative number of discoloration, erratic swimming, and mortality were monitored in-situ. The results showed that the lethal effect of the toxicants on the fishes depends on concentration and duration of exposure to the toxicant. Also in-situ observation showed that the cumulative average number of discoloration, erratic swimming, and mortality increased with increase in concentration and exposure time, while the cumulative average of operculum movement and tail beat frequency decreased with increase concentration and exposure time.
\end{abstract}

Keywords: Pesticides, Insecticides, Contaminants, Fish, Behaviour

\section{INTRODUCTION}

Fish is the cheapest animal protein source in Nigeria it is readily available, delicious, and has significant health impact (Fawole et al., 2007). It is a commonly traded food commodity in Nigeria and it is becoming the fastest growing 
agricultural item in international markets (Ariweriokuma et al., 2011). However, fish populations in diverse aquatic biota are susceptible to environmental impacts resulting from the addition of new and strange species, industrial wastes, oil spills, pesticides and toxicants or agents that directly affect the ecology of the aquatic environment. The specie Clarias gariepinus known as Africa mud catfish is a fresh water fish usually found in rivers, lakes, dams, muddy water, floods, swamps and other types of waters. C. gariepinus is the most popularly cultivated fish in Nigeria (Sogbesan and Ugwumba, 2006). It has adaptive features that enable it to bury itself under muddy water or river bed where there is a decrease in water level and can also gulp air directly using its accessory breathing organ without the use of its gills (De Moor and Bruton,1988). Fish cultivation is among the fastest growing sectors of the world's animal production with about $10 \%$ annual increase (FAO, 1997).

Contamination of water bodies often results from direct use of the harmful/injurious substance on the aquatic environment, and run-offs from land into water bodies (Nte and Akinrotimi, 2011). Continuous surface run-off of pesticides into water bodies can lead to high mortality rate of aquatic animals. It is observed that in developing and underdeveloped countries where wastes disposal system are not regulated, the aquatic environment often acts as a sink for toxic contaminants which are introduced from effluents of industrial, domestic and agricultural activities (Ariweriokuma et al., 2011; Nte et al., 2011). These toxic chemicals disturb the integrity of the aquatic environment and pose negative effects on the aquatic animals most importantly the fish (Uedeme-Naa et al., 2011). It is thus evident that oil industry activities like exploration, transportation, storage, oil spills, are sources of major contamination problems in most developing countries. Most oil spills on water bodies spread quickly within the water body into a slick, the most detrimental effect is seen when the oil strand on shorelines or settles into restricted shallow waters such as estuaries; resulting in long-term negative consequences.

Behavioural responses are very important indicators in the natural and/or external environment of animals. It is first visible sign of stress noticed in an organism. It is a promising tool in ecotoxicology. Behavioural and morphological changes in fish have been used as a diagnostic endpoint for screening and differentiating chemicals according to their mode of action (Farombi et al., 2008). Behavioural changes induced by petroleum-related toxicants, and pesticidal stress among others leads to alterations in the performance of the fish, which leads to retardation of growth and reduction in the fertility as well as longevity of the organism. Moreover, Tham et al. (2009) reported that fishes show restiveness, agitations, fast movement, cataclysm, respiratory issues, excess mucus secretion, colour changes, and losses balance when exposed to pesticides. Fishes are generally used to measure the health of an aquatic ecosystem; their physiological changes serving as biomarkers of environmental pollution (Köck et al., 1996). In toxicity studies, Clarias gariepinus is mostly used because of its tenacity to 
tolerate both well and poorly oxygenated waters. This study is therefore focussed on the behavioural responses of $C$. gariepinus exposed to some pesticides and petroleum based chemicals

\section{MATERIALS AND METHODS}

\section{Research design}

The experimental method adopted was static bioassay which was completely randomized with separate sets of concentrations, whereby a set comprises five treatments and a control. Each set has three replicates. This design was adopted for each of the toxicants. The experiment was done in different phase for each of the toxicant in two set ups. One set up was designed to test for acute toxicity of three pesticides paraquat dichloride (dragon), 2, 2-dichlorovinyl phosphate (DDVP) (Sniper) and lambda-cyhalothrin and dimethoate (kartodim $315 \mathrm{ec}$ ), the second was designed to test for the acute toxicity of three other toxicants dispersant, condensate, and oil based mud on the fish specimens, with the exposure of fishes to the toxicant observation and data collection of in-situ results.

\section{Experimental location and fish}

The experiment was performed at African Regional Aquaculture Centre, (ARAC), Aluu, in Ikwere Local Government Area Rivers State, Nigeria. Both phases of the experiment were carried out in the hatchery and at the disease laboratory unit of the centre. One thousand, three hundred apparently healthy specimens of Africa catfish (Clarias gariepinus) Juveniles of either sex were purchased on order from African Regional Aquaculture Centre (ARAC) Port Harcourt, Rivers State. The fishes were kept in the centre pond for acclimatization for seven days according to the method of Delorenzo et al. (2004), in two large aquaria. The fishes were not fed two days prior to exposure to the toxicants.

\section{Preparation of test solutions and exposure of fish}

The pesticides used were purchased from a commercial outlet, while the petroleum based chemicals used were obtained from an oil servicing company all in Port Harcourt, Nigeria. Acute renewal bioassay was conducted in the laboratory following OECD guidelines No 203 to determine the toxicity of the chemicals to $C$. gariepinus. Five concentrations each $100.0 \mathrm{mg} / \mathrm{L}, 200.0 \mathrm{mg} / \mathrm{L}$, $300.0 \mathrm{mg} / \mathrm{L}, 400.0 \mathrm{mg} / \mathrm{L}$ and $500.0 \mathrm{mg} / \mathrm{L}$ and control, $0.00 \mathrm{mg} / \mathrm{L}$ were prepared following the methods of dispensed into 30L tanks containing dechlorinated water. Ten fishes were randomly distributed into each test tank.

\section{Parametric observation and monitoring of exposed the fishes}

The following parameters were monitored immediately after stocking the fishes, and afterward at twelve hours regular intervals and until ninety-six hours $(0,12,24,36,48,60,72,84$, and $96 \mathrm{hrs})$. The parameters which were monitored with respect to change in concentration of the toxicants include: Operculum 
movement rate, per minute (OBF), discoloration, tail beat frequency (per minute) (TBF), erratic swimming, and mortality. These physicochemical parameters were done in-situ $\mathrm{pH}$ and temperature for all the toxicants. The materials used include cylindrical glass rod, and stop clock with alarm system, or stop watch. Operculum movement rate: Operculum beat frequency (OBF per minute) was monitored when the targeted fish is at rest. At each instance, stop watch or an alarm system stop clock was used. Operculum movement is the number of times the target fish moves its operculum within one minute. As the experiment progresses the number of discolored fish in each aquarium was noted. Discoloration is characterized by presence of white patches, and peeling of the outer layer of the fish body. Tail beat frequency, this parameter was monitored when the target fish is in motion, i.e. swimming. However, each time the fish stops abruptly, it was poked with a cylindrical glass rod. With the aid of the stop watch, the number of tail swinging within sixty seconds was noted. Each aquarium (tank) was monitored for fishes exhibiting erratic swimming. A fish is considered as swimming erratically if it is not swimming straight, but slant, and sluggishly due to weakness induced by the toxicant in the test solution. A fish regarded as exhibiting erratic swimming is intermittently poked with the cylindrical glass rod whether its speed will improve, in order to ascertain that it is really weak. Mortality in the aquarium (tank) was monitored for dead fishes. The number of dead fishes in each tank was noted at every instance. This was done cumulatively from 0-96 hrs.

\section{Statistical analysis}

The data obtained were statistically analyzed by using SPSS 16.0 software (SPSS, Inc., Chicago, IL). Data were subjected to one-way analysis of variance and Duncan's multiple range tests to determine the significant difference at the $5 \%$ probability level. Results were expressed as means standard deviation.

\section{RESULTS}

The results of observed anomalies in $C$. gariepinus exposed to different toxicants in the laboratory are presented in Tables 1 to 6 . Generally, the observed anomalies displayed by the fish increased with increasing concentration of all in toxicants in the aquaria. The opercula beat frequency (OBF) and tail beat frequency (TBF) increased significantly as the concentrations of the toxicants increased in all the chemicals under consideration. Also discolorations of some fish, signs of respiratory distress, loss of balance, erratic swimming eventually leading to death of some of the fishes was also noticed prior to mortality of the fishes, the extent of these anomalies were directly proportional to the toxicant concentration. For the fishes in the tanks having lower concentrations of toxicants $(0.1 \mathrm{~g} / \mathrm{L}$ and $0.2 \mathrm{~g} / \mathrm{L})$, there were relatively less visible anomalies in their behaviour. Comparatively the values of OBF were higher in both pesticides and petroleum based toxicants in all concentrations of exposure (Figure 1). However, 
fish exposed to condensate, consistently had the highest values in all concentrations (Figure 2). Conversely, skin discolouration in the exposed fish were more pronounced in the fish treated with pesticides than the oil based toxicants, with fish exposed to paraquats and DMC having the highest values (Figure 3).

Table 1. Variations in some behavioural responses of $C$. gariepinus exposed to paraquat dichloride (Mean $\pm \mathrm{SD}$ ).

\begin{tabular}{lcccccc}
\hline \multirow{2}{*}{ Parameters } & \multicolumn{5}{c}{ Concentrations of Chemical (mg/L) } \\
\cline { 2 - 7 } & $\mathbf{0 . 0 0}$ & $\mathbf{1 0 0 . 0 0}$ & $\mathbf{2 0 0 . 0 0}$ & $\mathbf{3 0 0 . 0 0}$ & $\mathbf{4 0 0 . 0 0}$ & $\mathbf{5 0 0 . 0 0}$ \\
\hline \multirow{2}{*}{ OBF/min } & $53.30 \pm 2.50^{\mathrm{a}}$ & $61.40 \pm 2.00^{\mathrm{a}}$ & $68.80 \pm 6.00^{\mathrm{a}}$ & $77.40 \pm 4.00^{\mathrm{b}}$ & $87.70 \pm 5.10^{\mathrm{c}}$ & $89.90 \pm 5.70^{\mathrm{c}}$ \\
Disc. & $00.00 \pm 0.00^{\mathrm{a}}$ & $16.00 \pm 2.00^{\mathrm{a}}$ & $26.10 \pm 3.00^{\mathrm{b}}$ & $29.00 \pm 2.00^{\mathrm{b}}$ & $37.00 \pm 4.00^{\mathrm{c}}$ & $39.00 \pm 4.60^{\mathrm{c}}$ \\
TBF/min & $51.00 \pm 0.00^{\mathrm{a}}$ & $64.00 \pm 3.00^{\mathrm{a}}$ & $69.10 \pm 0.00^{\mathrm{a}}$ & $75.00 \pm 3.00^{\mathrm{a}}$ & $85.00 \pm 5.00^{\mathrm{a}}$ & $89.60 \pm 5.80^{\mathrm{a}}$ \\
Err. S/min & $0.00 \pm 0.00^{\mathrm{a}}$ & $6.00 \pm 0.20^{\mathrm{a}}$ & $7.00 \pm 1.10^{\mathrm{a}}$ & $12.00 \pm 3.06^{\mathrm{b}}$ & $21.00 \pm 4.50^{\mathrm{c}}$ & $28.00 \pm 4.78^{\mathrm{c}}$
\end{tabular}

Note: Means in the same roll with different superscripts are significantly different $(P<0.05)$.

Key: OBF: Opercula Beat Frequency; Disc. : Skin Discoloration; TBF: Tail Beat Frequency; Err. Swim. : Erratic

Swimming.

Table 2. Variations in some behavioural responses of $C$. gariepinus exposed to DDVP, (Mean \pm SD).

\begin{tabular}{lcccccc}
\hline \multirow{2}{*}{ Parameters } & \multicolumn{5}{c}{ Concentrations of Chemical (mg/L) } \\
\cline { 2 - 7 } & $\mathbf{0 . 0 0}$ & $\mathbf{1 0 0 . 0 0}$ & $\mathbf{2 0 0 . 0 0}$ & $\mathbf{3 0 0 . 0 0}$ & $\mathbf{4 0 0 . 0 0}$ & $\mathbf{5 0 0 . 0 0}$ \\
\hline \multirow{2}{*}{ OBF/min } & $54.80 \pm 2.70^{\mathrm{a}}$ & $71.70 \pm 2.80^{\mathrm{a}}$ & $78.90 \pm 6.80^{\mathrm{a}}$ & $87.50 \pm 4.20^{\mathrm{b}}$ & $89.90 \pm 5.90^{\mathrm{c}}$ & $92.90 \pm 5.82^{\mathrm{c}}$ \\
Disc. & $00.00 \pm 0.00^{\mathrm{a}}$ & $10.00 \pm 2.80^{\mathrm{b}}$ & $12.10 \pm 3.10^{\mathrm{b}}$ & $18.70 \pm 2.09^{\mathrm{c}}$ & $18.80 \pm 4.90^{\mathrm{c}}$ & $19.20 \pm 4.40^{\mathrm{c}}$ \\
TBF/min & $52.00 \pm 3.20^{\mathrm{a}}$ & $74.00 \pm 3.60^{\mathrm{a}}$ & $79.80 \pm 7.70^{\mathrm{a}}$ & $85.80 \pm 3.70^{\mathrm{b}}$ & $89.90 \pm 5.50^{\mathrm{b}}$ & $92.90 \pm 5.80^{\mathrm{c}}$ \\
Err. S/min. & $0.00 \pm 0.00^{\mathrm{a}}$ & $13.10 \pm 0.20^{\mathrm{b}}$ & $14.00 \pm 1.10^{\mathrm{b}}$ & $16.00 \pm 3.06^{\mathrm{b}}$ & $19.00 \pm 4.50^{\mathrm{b}}$ & $23.00 \pm 4.80^{\mathrm{c}}$ \\
& & & & & & \\
\hline
\end{tabular}

Note: Means in the same roll with different superscripts are significantly different $(P<0.05)$.

Key: OBF: Opercula Beat Frequency; Disc. : Skin Discoloration; TBF: Tail Beat Frequency; Err. S.: Erratic Swimming. 
Table 3. Variations in some behavioural responses of C.gariepinus exposed to combined Dimethoate and $\lambda$-cyhalothrin (Mean $\pm \mathrm{SD}$ ).

\begin{tabular}{lcccccc}
\hline \multirow{2}{*}{ Parameters } & \multicolumn{5}{c}{ Concentrations of Chemical (mg/L) } \\
\cline { 2 - 7 } & $\mathbf{0 . 0 0}$ & $\mathbf{1 0 0 . 0 0}$ & $\mathbf{2 0 0 . 0 0}$ & $\mathbf{3 0 0 . 0 0}$ & $\mathbf{4 0 0 . 0 0}$ & $\mathbf{5 0 0 . 0 0}$ \\
\hline \multirow{2}{*}{ OBF/min } & $53.90 \pm 2.90^{\mathrm{a}}$ & $64.50 \pm 2.70^{\mathrm{a}}$ & $67.80 \pm 6.40^{\mathrm{a}}$ & $78.50 \pm 4.20^{\mathrm{b}}$ & $88.90 \pm 5.80^{\mathrm{c}}$ & $95.50 \pm 5.20^{\mathrm{d}}$ \\
Disc. & $00.00 \pm 0.00^{\mathrm{a}}$ & $10.00 \pm 2.90^{\mathrm{a}}$ & $16.10 \pm 3.10^{\mathrm{b}}$ & $19.00 \pm 2.80^{\mathrm{b}}$ & $35.00 \pm 4.90^{\mathrm{c}}$ & $38.00 \pm 4.20^{\mathrm{c}}$ \\
TBF/min & $51.90 \pm 2.70^{\mathrm{a}}$ & $68.70 \pm 3.20^{\mathrm{b}}$ & $69.90 \pm 5.10^{\mathrm{b}}$ & $72.80 \pm 3.20^{\mathrm{c}}$ & $76.80 \pm 5.70^{\mathrm{ac}}$ & $79.50 \pm 5.80^{\mathrm{c}}$ \\
Err. S/min & $0.00 \pm 0.00^{\mathrm{a}}$ & $8.30 \pm 1.20^{\mathrm{b}}$ & $10.01 \pm 1.40^{\mathrm{b}}$ & $15.50 \pm 3.66^{\mathrm{b}}$ & $21.90 \pm 4.80^{\mathrm{c}}$ & $25.10 \pm 4.10^{\mathrm{c}}$
\end{tabular}

Note: Means in the same roll with different superscripts are significantly different $(P<0.05)$.

Key: OBF: Opercula Beat Frequency; Disc. : Skin Discoloration; TBF: Tail Beat Frequency; Err. Swim. :

Erratic Swimming.

Table 4. Variations in some behavioural responses of C.gariepinus exposed to Oil dispersant (Mean $\pm \mathrm{SD}$ ).

\begin{tabular}{lcccccc}
\hline \multirow{2}{*}{ Parameters } & \multicolumn{6}{c}{ Concentrations of Chemical (mg/L) } \\
\cline { 2 - 7 } & $\mathbf{0 . 0 0}$ & $\mathbf{1 0 0 . 0 0}$ & $\mathbf{2 0 0 . 0 0}$ & $\mathbf{3 0 0 . 0 0}$ & $\mathbf{4 0 0 . 0 0}$ & $\mathbf{5 0 0 . 0 0}$ \\
\hline \multirow{2}{*}{ OBF/min } & $53.80 \pm 2.50^{\mathrm{a}}$ & $62.70 \pm 2.00^{\mathrm{b}}$ & $65.80 \pm 6.30^{\mathrm{b}}$ & $67.80 \pm 4.23^{\mathrm{b}}$ & $77.90 \pm 6.20^{\mathrm{c}}$ & $79.30 \pm 6.70^{\mathrm{c}}$ \\
Disc. & $00.00 \pm 0.00^{\mathrm{a}}$ & $12.00 \pm 3.00^{\mathrm{b}}$ & $16.10 \pm 3.00^{\mathrm{b}}$ & $22.00 \pm 2.10^{\mathrm{c}}$ & $26.00 \pm 4.01^{\mathrm{c}}$ & $28.00 \pm 5.71^{\mathrm{c}}$ \\
$\mathrm{TBF} / \min$ & $51.50 \pm 0.00^{\mathrm{a}}$ & $64.40 \pm 3.00^{\mathrm{b}}$ & $69.90 \pm 0.00^{\mathrm{b}}$ & $76.20 \pm 3.00^{\mathrm{b}}$ & $88.10 \pm 5.20^{\mathrm{c}}$ & $92.10 \pm 5.70^{\mathrm{c}}$ \\
Err. S/min & $0.00 \pm 0.00^{\mathrm{a}}$ & $5.00 \pm 0.20^{\mathrm{b}}$ & $11.00 \pm 1.50^{\mathrm{c}}$ & $12.00 \pm 3.86^{\mathrm{c}}$ & $25.00 \pm 4.50^{\mathrm{d}}$ & $28.00 \pm 4.90^{\mathrm{d}}$
\end{tabular}

Note: Means in the same roll with different superscripts are significantly different $(P<0.05)$.

Table 5. Variations in some behavioural responses of $C$.gariepinus exposed to condensate (Mean $\pm \mathrm{SD})$.

\begin{tabular}{lcccccc}
\hline \multirow{2}{*}{ Parameters } & \multicolumn{5}{c}{ Concentrations of Chemical (mg/L) } \\
\cline { 2 - 7 } & $\mathbf{0 . 0 0}$ & $\mathbf{1 0 0 . 0 0}$ & $\mathbf{2 0 0 . 0 0}$ & $\mathbf{3 0 0 . 0 0}$ & $\mathbf{4 0 0 . 0 0}$ & $\mathbf{5 0 0 . 0 0}$ \\
\hline \multirow{2}{*}{ OBF/min } & $54.30 \pm 2.70^{\mathrm{a}}$ & $81.75 \pm 2.80^{\mathrm{b}}$ & $88.60 \pm 6.80^{\mathrm{b}}$ & $93.50 \pm 4.70^{\mathrm{c}}$ & $99.90 \pm 5.80^{\mathrm{c}}$ & $104.91 \pm 7.45^{\mathrm{c}}$ \\
Disc. & $00.00 \pm 0.00^{\mathrm{a}}$ & $11.00 \pm 2.86^{\mathrm{a}}$ & $15.18 \pm 3.22^{\mathrm{b}}$ & $25.50 \pm 2.19^{\mathrm{b}}$ & $30.80 \pm 4.20^{\mathrm{c}}$ & $30.80 \pm 4.20^{\mathrm{c}}$ \\
TBF/min & $52.00 \pm 3.20^{\mathrm{a}}$ & $74.00 \pm 3.60^{\mathrm{b}}$ & $79.80 \pm 7.70^{\mathrm{b}}$ & $85.80 \pm 3.70^{\mathrm{c}}$ & $89.90 \pm 5.50^{\mathrm{c}}$ & $94.30 \pm 5.21^{\mathrm{d}}$ \\
Err. S.min. & $0.00 \pm 0.00^{\mathrm{a}}$ & $12.80 \pm 1.20^{\mathrm{b}}$ & $14.00 \pm 1.90^{\mathrm{b}}$ & $25.00 \pm 3.26^{\mathrm{c}}$ & $29.00 \pm 4.70^{\mathrm{c}}$ & $32.00 \pm 4.31^{\mathrm{c}}$ \\
\hline
\end{tabular}

Note: Means in the same roll with different superscripts are significantly different $(P<0.05)$.

Key: OBF: Opercula Beat Frequency; Disc. : Skin Discoloration; TBF: Tail Beat Frequency; Err. Swim. :

Erratic Swimming. 
Table 6. Variations in some behavioural responses of C.gariepinus exposed to Oil based mud (Mean \pm SD).

\begin{tabular}{lcccccc}
\hline \multirow{2}{*}{ Parameters } & \multicolumn{6}{c}{ Concentrations of Chemical $(\mathbf{m g} / \mathbf{L})$} \\
\cline { 2 - 7 } & $\mathbf{0 . 0 0}$ & $\mathbf{1 0 0 . 0 0}$ & $\mathbf{2 0 0 . 0 0}$ & $\mathbf{3 0 0 . 0 0}$ & $\mathbf{4 0 0 . 0 0}$ & $\mathbf{5 0 0 . 0 0}$ \\
\hline \multirow{2}{*}{ OBF/min } & $54.20 \pm 2.30^{\mathrm{a}}$ & $74.70 \pm 2.20^{\mathrm{b}}$ & $77.10 \pm 6.60^{\mathrm{b}}$ & $88.20 \pm 4.90^{\mathrm{c}}$ & $90.90 \pm 5.30^{\mathrm{c}}$ & $95.20 \pm 5.40^{\mathrm{c}}$ \\
Disc. & $00.00 \pm 0.00^{\mathrm{a}}$ & $12.00 \pm 2.20^{\mathrm{a}}$ & $17.80 \pm 3.90^{\mathrm{b}}$ & $23.06 \pm 2.20^{\mathrm{b}}$ & $28.08 \pm 4.91^{\mathrm{c}}$ & $32.08 \pm 4.11^{\mathrm{c}}$ \\
TBF/min & $52.10 \pm 2.40^{\mathrm{a}}$ & $69.10 \pm 3.10^{\mathrm{a}}$ & $79.99 \pm 5.92^{\mathrm{a}}$ & $80 . .80 \pm 3.10^{\mathrm{a}}$ & $88.80 \pm 5.88^{\mathrm{a}}$ & $92.10 \pm 5.11^{\mathrm{a}}$ \\
Err. S/min. & $0.00 \pm 0.00^{\mathrm{a}}$ & $10.00 \pm 1.20^{\mathrm{a}}$ & $10.01 \pm 1.40^{\mathrm{a}}$ & $19.30 \pm 3.99^{\mathrm{a}}$ & $30.90 \pm 6.80^{\mathrm{a}}$ & $34.33 \pm 6.32^{\mathrm{a}}$ \\
& & & & & & \\
\hline
\end{tabular}

Note: Means in the same roll with different superscripts are significantly different $(P<0.05)$.

Key: OBF: Opercula Beat Frequency; Disc. : Skin Discoloration; TBF: Tail Beat Frequency; Err. Swim. : Erratic Swimming.

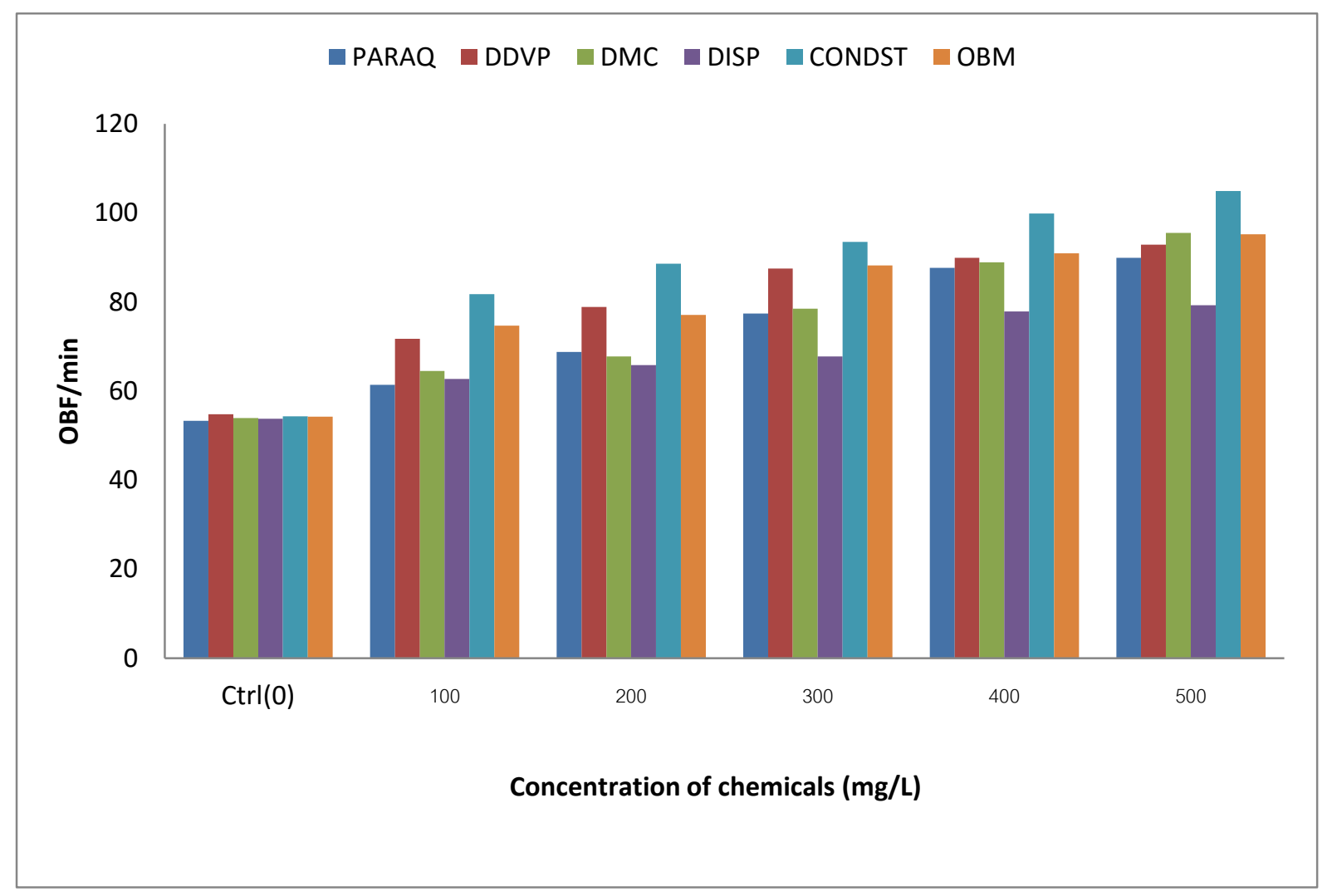

Figure 1. Comparative values of opercula beat frequency (OBF) in C.gariepinus exposed to different chemicals in the laboratory. 


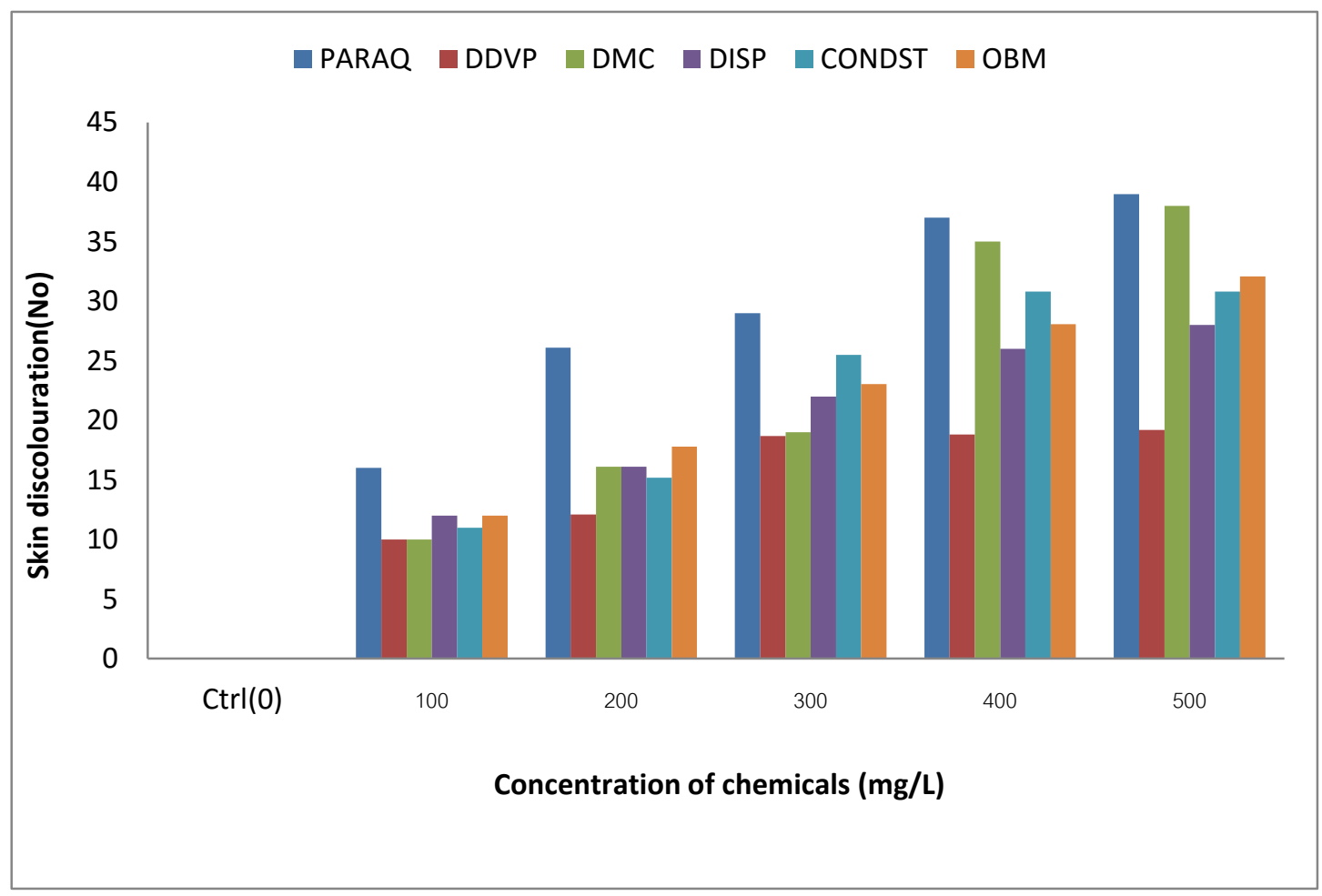

Figure 2. Comparative values of skin discolouration in C.gariepinus exposed to different chemicals in the laboratory.

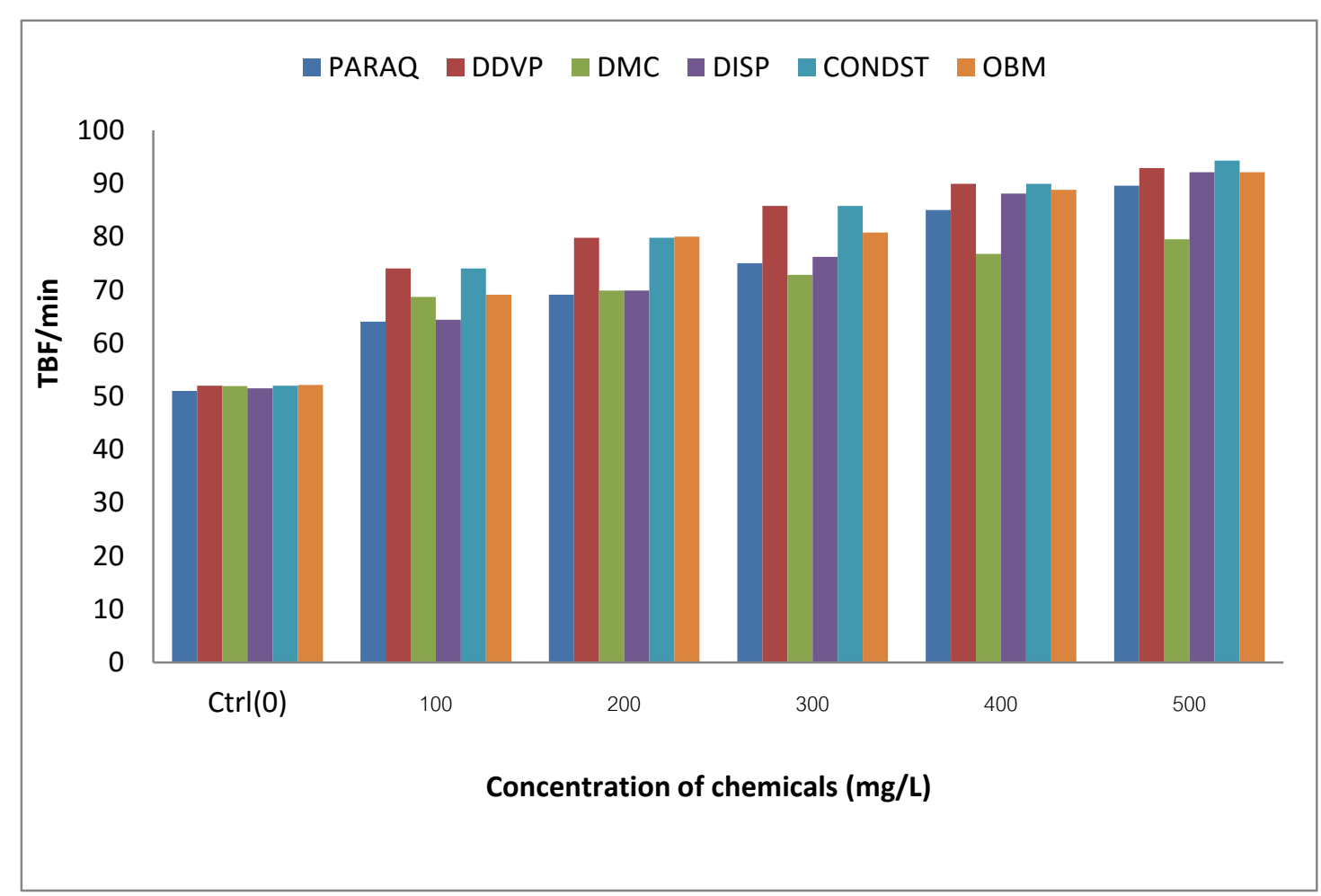

Figure 3. Comparative values of tail beat frequency (TBF) in C.gariepinus exposed to different chemicals in the laboratory. 


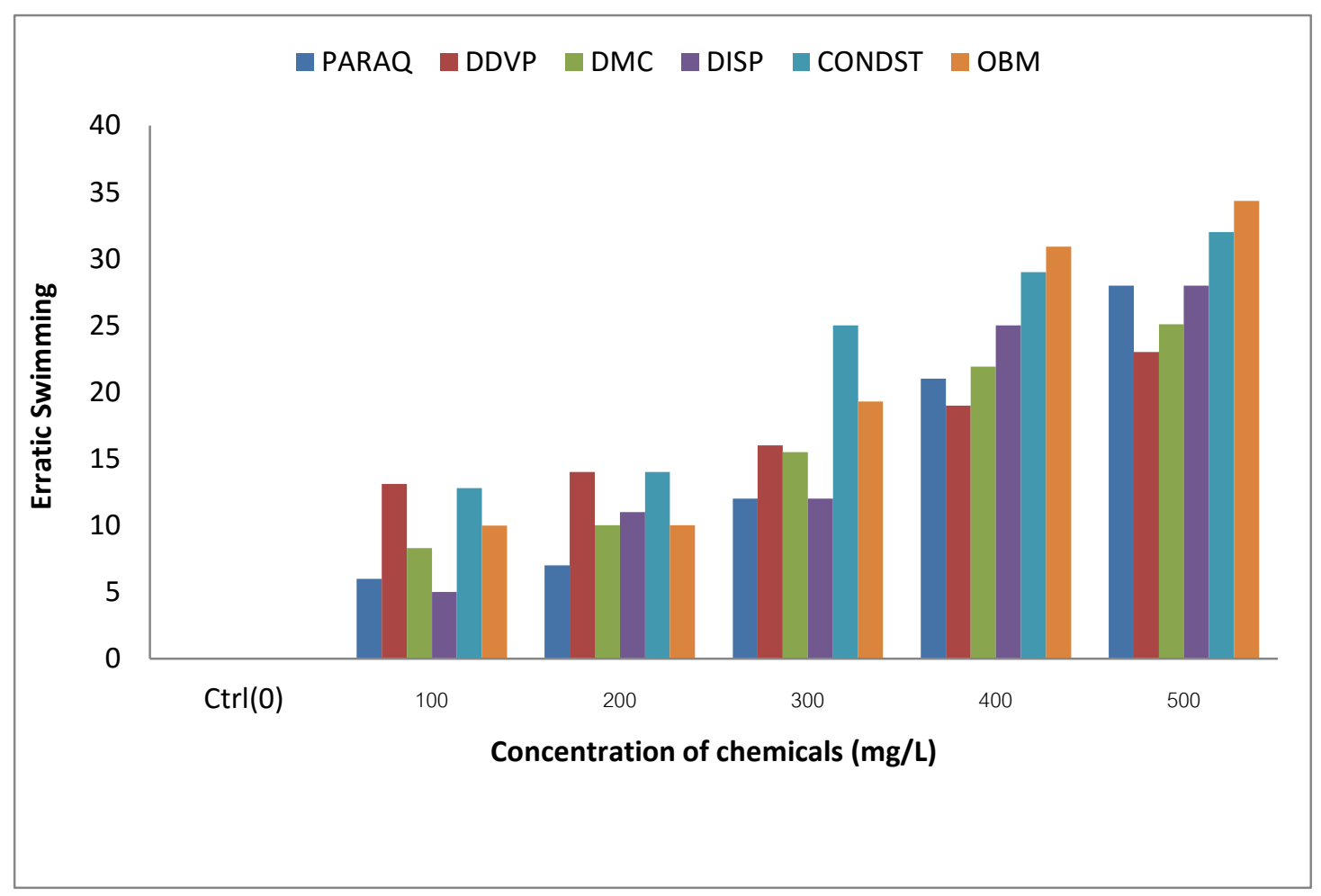

Figure 4. Comparative values of Erratic Swimming in C.gariepinus exposed to different chemicals in the laboratory.

\section{DISCUSSION}

Some behavioral anomalies were noted at various instances after the fishes were introduced into the various toxicants solutions. The abnormal behaviour exhibited include strong restlessness and excitation, this was reflected by an increased reaction to stimuli, loss of movement co-ordination as well as loss of orientation (erratic swimming). Some of the fishes, especially those that received the highest concentration of the toxicant attempted jumping out of the toxicants solution, rapid opercula movement and incessant gulping of air were obvious.

The behavioural changes are directly related to complex physiological responses and have often been used as a sensitive indicator of stress (Shalaby et al., 2006; Shallangwa and Auta, 2008).The present investigation showed that exposure of $C$. gariepinus to some of pesticides and petroleum based chemicals in water induces a variety of abnormalities in the behavior of the fish. In assessment of the whole body response, observation was made on what happened to the fish immediately after been exposed to sub-lethal concentration of these toxicants. Discoloration was a common phenomenon in all the chemicals under consideration. The body colour changed from original silvery dark to pale silvery white colour in pesticide and petroleum exposed fish. The fishes exposed in experimental tanks without chemical (control aquaria) behaved normal. Changes in body colour have been reported in Anabas testudineus and Channa punctatus 
after exposure to diazinon, $C$. punctatus to glyphosate and red drum fish to atrazine (Sritbanditmongkol et al., 2012: Banik et al., 2017).

Exposure of C.gariepinus to these chemicals, resulted in erratic swimming, abnormal posture, sluggishness, increase in surface activity, gradual loss of equilibrium and spreading of excess of mucus all over the surface of the body. Occasionally the fish tried jumping out of the toxic medium, which showed the avoidance behaviour of the fish to the toxicant. These observations agree with the findings of Aderolu et al. (2010) in C. gariepinus exposed to pesticides. Many workers (Trissel et al., 2004; Ogueji and Auta, 2008, Bhavani et al., 2012) all has observed erratic swimming, equilibrium loss and surfacing phenomenon in the fish following pesticide exposure. Surfacing phenomenon shown by the fish might be to gulp maximum possible air to ease the tension (Auta and Ogueji, 2006). David et al. (2003) also observed this phenomenon in the fish, Tilapia mossambica exposed to cypermethrin. In relation to this they also reported that the surfacing phenomenon was due to hypoxic condition of the fish.

These behavioural changes may be due to nervous impairment due to blockade of nervous transmission among the system and various effector sites (Aguigwo, 2002). Moreover, reports were made by Al-Snafi (2016) reported that hyperactivity of fish on introduction to an unfavourable environment as the primary and principal sign of system failure due to chemical poisoning which affected physiological activities. Katagi (2010) noted also disruption of the functioning of the nervous system of fish, resulting in slow and lethargic swimming, erratic movement and loss of equilibrium. The fish were also found to secrete mucous on the gill filament and body surface prior to death following pesticide and oil based chemicals poisoning. This phenomenon is evidently a symptom of the inflammatory reaction of the gill and body surface to the toxicant. Similar findings were made by many authors (Hoyle et al., 2007; Kaoud et al., 2011; El-Sadaawy et al., 2013), who studied the effect of different chemicals on fish.

The beat frequency of $C$. gariepinus exposed to the various concentrations of toxicants in this study was used to measure the respiratory rate. The tail fin beat of fish to the toxicant were higher than in control fish at all concentrations in all the chemicals under consideration. The increase in tail fin beat may be associated with sudden response of the fish to the shock of exposure to the chemical (Rabitto et al., 2005). This also indicates hyper ventilation to cope at the initial period but with increase in exposure, the fish become weaker and finally die due to suffocation. Similar findings were reported by Palaniappan et al., (2008) in the fish exposed to toxicants in the laboratory.

The opercula beat frequencies of $C$. gariepinus to the toxicant were higher than in control fish at the 96 hour exposure time. The increase in opercula beat frequency may also be associated with sudden response of the fish to the shock of exposure to the agro-based and petroleum based chemical (Glusczak et al., 2011). This also indicates hyperventilation to cope at the initial period but with 
increase in exposure, the fish become weak and finally die due to suffocation. Similar findings were reported by Hossain et al., 1987; Mishra et al., 2001; and Linde et al., 2004. The opercula movement in rainbow trout fish has been reported to increase with increasing concentrations (Pandey et al., 2008). These behaviour patterns suggest respiratory impairment, probably due to the effect of the toxicant on the gills and general metabolism. The rapid opercula movements may be due to accumulation of mucous over gill due to the toxicant (Spokas et al., 2006).

\section{CONCLUSION}

The result of this research showed that $96 \mathrm{hrs}$ exposure of African catfish, Clarias gariepinus to the toxicants which are dragon, sniper, kartodim $315 \mathrm{ec}$, dispersant, condensate, and OBM. drastically influenced the content of electrolytes: (sodium, potassium, chloride, calcium and hydrogen carbonate) in the fish organs. Generally, the temperature and phosphate values for all the toxicants corresponded significantly $(P<0.05)$ with their respective control values. There were some behavioral anomalies detected during the research, these includes resilient restlessness and excitation. It was observed that the tail beat frequency of $C$. gariepinus which measured the respiratory rate were higher in all toxicant concentrations than in control. The increase in exposure of African catfish to different toxicant, caused a lot of abnormal behaviors such as erratic swimming, abnormal posture, sluggishness, increase in surface activity, gradual loss of equilibrium and spreading of excess of mucus all over the surface of the body. Other defects such as discoloration, irregular breathing and swimming pattern were also observed. Finally, fish mortalities were also recorded.

\section{ACKNOWLEDGEMENTS}

The authors are grateful to the management and staff of African Regional Aquaculture Centre (ARAC) Aluu, Port Harcourt, Rivers State for grating us access to their facility during the acclimatization and period of carrying out this research. The contributions of Dr. (Mrs) E. Ansa, Dr. O. Akinrotimi and Dr. Oyebade B. are gracefully acknowledged.

\section{REFERENCES}

Aderolu, A.Z., Ayoola, S.O., and Otitoloju, A.A. 2010. Effects of acute and sub-lethal concentrations of Actellic on weight changes and haematology parameters of Clarias gariepinus. World Journal of Biological Research. 3: 30-39. 
Aguigwo, J.N., 2002. The toxic effect of cymbush pesticide on growth and survival of Africa catfish Clarias gariepinus (Burchell). Journal of Aquatic Scinces. 17(2): 81-84. https://doi.org/10.4314/jas.r17i2.19916

Al-Snafi, A.E. 2016. Adonis aestivalis: pharmacological and toxicological activities-A review. Asian Journal of Pharmaceutical Science \& Technology. 6(2): 96-102.

Ariweriokuma, S.U., Akirotimi, O.A., and Gabriel, U.U. 2011. Effects of Cypermethrin on condition factor and organosomatic indices of Clarias gariepinus. Journal of Agriculture and Social Research. 11(2): 67-72.

Auta, J., and Ogueji, E.O. 2006. Sublethal effect of dimethoate on growth and food utilization of Oreochromis niloticus (Trewavas). Journal of Biosciences. 1: 163-166.

Banik, U., Rahman, M.M., Khanam, T., and Mollah, M.F.A. 2017. Histopathological changes in the gonads, liver, and kidney of Glossogobiusgiuris exposed to sub-lethal concentration of diazinon. Progressive Agriculture. 27(4): 530-538. https://doi.org/10.3329/pa. v27i4.32143

Bhavani, G., Obaiah, J., and Usha Rani, A. 2012. Possible protection of calcium against cadmium induced bioaccumulation and alterations in selected oxidative stress enzymes in the fresh water teleost, Oreochromis mossambicus (Tilapia). Indian Journal.

David M., Shivakumar H.B., Shivakumar R., Mushigeri S.B., and Ganthi B.H. 2003. Toxicity evalution of cypermethrin and its effect on oxygen consumption of the fresh water fish, Tilapia mossambica. Indian Journal of Environmental Toxicology. 13: 99-102.

Delorenzo, M.E., Downing, H.F., Fulton, M.H., Scott, G.I., Madden, C.J., and Kucklick, J.R. 2004. Effects of the agricultural pesticides atrazine, chlorothalonil, and endosulfan on South Florida microbial assemblages. Ecotoxicology. 13(3): 245-260. https://doi.org/10.1023/B:ECTX.000002 3569.46544.gf

De Moor, I.J., and Bruton, M.N. 1988. Atlas of alien and translocated indigenous aquatic animals in southern Africa. A report of the committee for Nature Conservation Research National Programme for Ecosystem Research. South African Scientific Programme Report No.144. Port Elizabeth, South Africa.

El-Sadaawy, M.M., El-Said, G.F., and Sallam, N.A. 2013. Bioavailability of heavy metals in fresh water Tilapia nilotica (Oreachromis niloticus Linnaeus, 1758): potential risk to fishermen and consumers. Journal of Environmental Science and Health, Part B. 48(5): 402-409. https://doi.org/ 10.1080/03601234.2013.742719

FAO. 1997. Food and Agricultural Organization of the United Nations, Review of the State of World Aquaculture. FAO Fisheries Circular No. 886, Rev.1.Rome, Italy. 
Farombi, E.O., Adelowo, O.A., and Ajimoko, Y.R. 2008. Biomarkers of oxidative stress and heavy metal levels as indicators of environmental pollution in African catfish (Clarias gariepinus) from Nigeria Ogun River. International Journal of Environmental Research and Public Health. 4(2): 158-165. https://doi.org/10.3390/ijerph2007040011

Fawole, O.O., Ogundiran, M.A., Ayandiran, T.A., and Olagunju, O.F. 2007. Proximate and mineral composition in some selected fresh water fishes in Nigeria. Internet Journal of Food Safety. 9: 52-55.

Glusczak L., Loro V.L., Pretto A., Moreas B.S., Raabe A., Duarte M.F., Da Fonseca, M.B., De Menezes, C.C., and Valladão, D.M. 2011. Acute exposure to glyphosate herbicide affects oxidative parameters in piava (Leporinus obtusidens). Archieves of Environmental Contamination and Toxicology. 61(4): 624-630. https://doi.org/10.1007/s00244-011-9652-4

Hossain, M.M., Ghatak, D.B., and Konar, S.K. 1987. Acute toxicity of mixture of non-ionic detergent Ekaline and an organic pesticide DDVP to fish, plankton and worm. Environment and Ecology. 5: 778-781.

Hoyle, I., Shaw, B.J., and Handy, R.D. 2007. Dietary copper exposure in the African walking catfish, Clarias geriepinus: transient osmoregulatory disturbances and oxidative stress. Aquatic Toxicology. 83(1): 62-72. https://doi.org/10.1016/j.aqutox.2007.03.014

Kaoud, H.A., Zaki, M.M., El-Dahshan, A.R., Saeid, S., and El Zorba, H.Y. 2011. Amelioration the toxic effects of cadmium exposure in Nile Tilapia (Oreochromis niloticus) by using Lemna gibba L. Life Science Journal. 8(1): 185-195.

Katagi, T. 2010. Bioconcentration, bioaccumulation, and metabolism of pesticides in aquatic organisms. Review of Environmental Contamination and Toxicology. 204: 1-132. https://doi.org/10.1007/978-1-4419-1440-8_1

Köck, G., Triendl, M., and Hofer, R. 1996. Seasonal patterns of metal accumulation in Arctic char (Salvelinus alpinus) from an oligotrophic Alpine lake related to temperature. Canadian Journal of Fisheries and Aquatic Sciences. 53(4): 780-786. https://doi.org/10.1139/f95-243

Linde, A.R., Sanchez-Galan, S., and Garcia-Vazquez, E. 2004. Heavy metal contamination of European eel (Anguilla anguilla) and brown trout (Salmo trutta) caught in wild ecosystems in Spain. Journal of Food Protection. 67(10): 2332-2336. https://doi.org/10.4315/0362-028X-67.10.2332

Mishra, D., Srivastav, S., Srivastav, S.K., and Srivastav, A.K. 2001. Plasma calcium and inorganic phosphate levels of a freshwater catfish Heteropneustes fossilis in response to cypermethrin treatment. Journal of Ecophysiology and Occupational Health. 1(1): 131-138.

Nte, M.E., and Akinrotimi, O.A. 2011. Biochemical changes in black jaw tilapia (Sarotherodon melanotheron) treated with sub lethal levels of industrial effluents. Advances in Agriculture, Science and Engineering Research. 1(2): 25-33. 
Nte, M.D., Hart, A.I., Edun, O.M., and Akinrotimi, O.A. 2011. Alterations in enzymes activities as a biomarker in blackjaw tilapia (Sarotherodon melanotehron) exposed to industrial effluents. Continental Journal of Biological Science. 4(2): 37-44.

Ogueji, E.O., and Auta, J. 2008. Effect of sub-lethal doses of chorpyrifos-ethyl on some biochemical parameters of African catfish Clarlas geriepinus. Global Journal of Pure and Applied Sciences. 13(93): 369-372. https://doi.org/10.4314/gjpas.v13i3.16720

Palaniappan, P.R., Sabhanayakam, S., Krishnakumar, N., and Vadivelu, M. 2008. Morphological changes due to lead exposure and the influence of DMSA on the gill tissues of the freshwater fish, Catlacatla. Food and Chemical Toxicology. 46(7): 2440-2444. https://doi.org/10.1016/j.fct.2008.03.028

Pandey, S., Parvez, S., Ansari, R.A., Ali, M., Kaur, M., Hayat, F., and Raisuddin, S. 2008. Effects of exposure to multiple trace metals on biochemical, histological and ultrastructural features of gills of a freshwater fish, Channa punctata Bloch. Chemico-Biological Interactions. 174(3): 183-192. https://doi.org/10.1016/j.cbi.2008.05.014

Rabitto I.S., Alves Costa, J.R., Silve de Assis, H.C., Pelletier, E.F., Akaishi, F.M., Anjos, A., Randi, M.A., and Oliveira Ribeiro, C.A. 2005. Effects of dietary $\mathrm{Pb}(\mathrm{II})$ and tributyltin on neotropical fish, Hoplias malabaricus: histopathological and biochemical findings. Ecotoxicology and Environmental Safety. 60: 147-156.

Shalaby, A.M., Khattab, Y.A., and Abdel Rahman, A.M. 2006. Effects of Garlic (Alliumsativum) and chloramphenicol on growth performance, physiological parameters and survival of Nile tilapia (Oreochromis niloticus). Journal of Venomous Animals and Toxins including Tropical Diseases. 12(2): 172-201. https://doi.org/10.1590/S1678-9199200600020 0003

Shallangwa, S.M., and Auta, J. 2008. Sub-lethal effect of 2,4- Dichlorophenoxyacetic acid on growth and food utilization of the African catfish Clarias gariepinus (Teugels). Journal of Fisheries International. 3(3): 65-67.

Sogbesan, O.A., and Ugwumba, A.A. 2006. Bionomics evaluation of garden snail (Limicolaria aurora, Jay, 1937; Gastropoda: Limicolaria) meat meal in the diet of Clarias gariepinus fingerlings (Burchell, 1822). Nigerian Journal of Fisheries. 2(3): 358-371.

Spokas, E.G., Spur, B.W., Smith, H., Kemp, F.W., and Bogden, J.D. 2006. Tissue lead concentration during chronic exposure of Pimephales promelas (fathead minnow) to lead nitrate in aquarium water. Environmental Science \& Technology. 40(21): 6852-6858. 
Sribanditmongkol, P., Jutavijittum, P., Pongraveevongsa, P., Wunnapuk, K., and Durongkadech, P. 2012. Pathological and toxicological findings in glyphosate-surfactant herbicide fatality: a case report. The American Journal of Forensic Medicine and Pathology. 33(3): 234-237. https://doi.org/10.1097/PAF.0b013e31824b936c

Tham, I.W.K., Hee, S.W., Yeo, R.M.C., Salleh, P.B., Lee, J., Tan, T.W.K., and Wee, J.T.S. 2009. Treatment of nasopharyngeal carcinoma using intensitymodulated radiotherapy-The National Cancer Centre Singapore experience. International Journal of Radiation Oncology, Biology, Physics. 75(5): 1481-1486. https://doi.org/10.1016/j.ijrobp.2009.01.018

Trissel, L.A., Saenz, C.A., Ogundele, A.B., and Ingram, D.S. 2004. Physical compatibility of pemetrexed disodium with other drugs during simulated Y-site administration. American Journal of Health-System Pharmacy. 61(21): 2289-2293. https://doi.org/10.1093/ajhp/61.21.22

Uedeme-Naa, B., Gabriel, U.U., and Akinrotimi, O.A. 2011. Relationship between aquatic macrophytes and water quality in Nta-Wogba stream, Port Harcourt, Nigeria. Continental Journal of Fisheries and Aquatic Science. 5(2): 6-16. 